\title{
I litteraturlaboratoriet. Didaktisk praksis for litterar kompetanse
}

\author{
Lars August Fodstad ${ }^{1 \star}$ og Maja Myhre Thomassen ${ }^{2}$ \\ ${ }^{1}$ Norges teknisk-naturvitenskapelige universitet og ${ }^{2}$ Sortland videregående skole
}

\begin{abstract}
Sammendrag
Artikkelen undersøker i hvilken grad og på hvilke måter visse undervisningsaktiviteter legger til rette for utvikling av elevers utvikling av litterær kompetanse i norskfaget på videregående skole. Utgangspunktet er Sheridan Blaus modell for litterær kompetanse, som inkluderer de tre bestanddelene tekstuell literacy, intertekstuell literacy og performativ literacy. Som et premiss for modellen ligger synet på skjønnlitteratur som autentiske problem hvor elevleserne må lære seg vedvarende konsentrert oppmerksomhet, toleranse for usikkerhet, samt å takle uenighet i tolkningsfellesskap. Gjennom observasjon og intervjuer analyseres og drøftes elevenes respons på og opplevelse av litteraturundervisningen, med vekt på elementer som nærlesning, notatskriving, ulike samtaleformer og metakognitiv refleksjon. Slik tilbyr studien en praksisnær utforskning av litteraturundervisning i norskfaget.
\end{abstract}

\section{Nøkkelord: Littercer kompetanse; litteraturundervisning; Sheridan Blau}

\begin{abstract}
In the Literature Laboratory. Didactics for Literacy Competence

This article explores to what extent and in what ways certain teaching activities facilitate the development of students' literary competence in Norwegian upper secondary L1 education. The investigation's point of departure is Sheridan Blau's literary competence model, which includes the three components textual literacy, intertextual literacy, and performative literacy. This model's main premise is an understanding of literature as authentic problems requiring the reading students to learn sustained concentrated attention, tolerance for uncertainty, and the ability to deal with disagreement in communities of interpretation. Through observation and interviews the students' response to and experience with the literature instruction is analyzed and discussed, emphasizing elements such as close reading, note writing, different forms of conversation, and metacognitive reflection. Thus, the study offers a practice-oriented exploration of literature instruction in Norwegian L1 education.
\end{abstract}

Keywords: Literary competence; teaching of literature; Sheridan Blau

Responsible editor: Atle Skaftun

Received: November, 2019; Accepted: March, 2020; Published: May, 2020

^Korrespondanse: Lars August Fodstad, epost: lars.fodstad@ntnu.no

(C) 2020 Lars August Fodstad og Maja Myhre Thomassen. This is an Open Access article distributed under the terms of the Creative Commons Attribution 4.0 International License (https://creativecommons.org/licenses/by-nc/4.0/), allowing third parties to copy and redistribute the material in any medium or format and to remix, transform, and build upon the material for any purpose, even commercially, provided the original work is properly cited and states its license. 


\section{Innledning}

Det overordnede forskningsspørsmålet i denne artikkelen er hvordan norsklæreren kan legge til rette for en litteraturdidaktisk praksis som fremmer litterær kompetanse. ${ }^{1}$ Tilnærmingen vår er praksisnær og kasusorientert idet vi undersøker og vurderer gjennomføringen og konsekvensene av konkrete læringsaktiviteter. Vi spør hvorvidt og hvordan den praktiserte undervisningen skapte forutsetninger for utvikling av elevenes litterære kompetanse. Dermed ligger det også en profesjonsutviklingsdimensjon i prosjektet vårt, ved at vi ønsker å eksemplifisere hvordan norsklærere kan drive didaktisk utviklingsarbeid og skape praksisnær kunnskap i skjæringspunktet mellom erfaring og forskning.

Fra og med Kunnskapsløftet har opplæringen i norsk skole vært basert på et kompetansesyn som ligger tett på literacy-begrepet (jf. Berge, 2005, s. 165), noe som også kan sies å videreføres med fagfornyelsens vektlegging av dybdelæring. Dette innebærer blant annet at lesekompetanse forstås som en forutsetning for å kunne forstå, lære og utøve fag. I norskfaget innebærer dette blant annet å kunne lese og skape mening av skjønnlitterære tekster, noe som dessuten blir mer eksplisitt formulert i den fornyede planen, hvor begrepet "skjønnlitteratur» er mer fremtredende enn i utgående plan.

Flere forskere har fremhevet betydningen av litterær kompetanse i dagens tekstsamfunn, og hevdet den inngår i en literacy-orientert opplæring (jf. Penne, 2010; Penne, 2013; Skaftun, 2009; Skarstein, 2013; Skaftun, Aasen \& Wagner, 2015; Steffensen, 2005). Imidlertid viser studier at skjønnlitteraturen ikke lenger har like stor plass i nordiske morsmålsfag (Krogh, Penne \& Ulfgard, 2012), og flere forskningsbidrag tyder på at nordiske elever har manglende litterær kompetanse. Flere begynner på videregående skole uten å ha lest en hel skjønnlitterær bok, de har lite erfaring med fiktive lesemåter (Krogh et al., 2012; Penne, 2012), og mange elever sliter med å lese fiktivt (Olin-Scheller, 2006; Penne, 2013). I stedet for å konstruere litterære forestillingsverdener og forholde seg utforskende til litteraturen, søker de umiddelbar gjenkjennelse gjennom koblinger til egen livsverden. Ifølge Penne (2010, s. 243) viser gjennomgang av skandinavisk klasseromsforskning at elever møter litteratur, medier og film med for mye nærhet og uklare grenser mellom fakta og fiksjon. Dette underbygges av Olle Nordberg, som i en gjennomgang av svensk litteraturdidaktisk forskning etter årtusenskiftet blant annet konkluderer med at den - på tvers av teoretisk-metodiske skillelinjer - dokumenterer elevers «subjektiva och förhollandevis okritiska» lesemåter og en tendens til å lese fiksjon med en "dokumentär attityd» (Nordberg, 2017, s. 35).

\footnotetext{
${ }^{1}$ Begrepet littercer kompetanse presenteres nedenfor, men allerede her bør det understrekes at vi bruker det i betydningen skjønnlittercer kompetanse, altså kompetanse i å lese spesifikt skjønnlitterære tekster. Begrepsbruken er i tråd med relevant teori- og forskningslitteratur på feltet (jf. Blau, 2003a; Culler, 1975; Torell, von Bonsdorff, Bläckmann \& Gontjarova, 2002).
} 
I senere år har vi fått flere undersøkelser av elevers møte med utfordrende tekster og hvilket potensial for meningsskaping, autentisk problemløsing og engasjement som ligger i disse møtene (Gourvennec, 2017; Johansen, 2015; Sønneland, 2019). Andre har undersøkt litterær kompetanse på ulike stadier i utdanningsløpet, fra hvordan begrepet forstås blant lærere i henholdsvis ungdomsskolen og videregående (Fodstad \& Gagnat, 2019; Kjelen, 2013), til hvilken litterær kompetanse henholdsvis avgangselever (Nordberg, 2017) og lærerstudenter dokumenterer (Kjelen, 2014). Hvordan spesifikke læringsaktiviteter kan legge til rette for utvikling av visse litterære delkompetanser, er imidlertid mindre utforsket, og det er dette vi vil studere her.

Undersøkelsen er utformet som en kvalitativ kasusstudie av praktisert undervisning, med datainnsamling $\mathrm{i}$ form av deltakende observasjon og semistrukturerte intervjuer. Undervisningskasuset bestod av tre økter med læringsaktiviteter hentet fra Sheridan Blaus bok The Literature Workshop. Teaching Texts and Their Readers (2003a). ${ }^{2}$ Vi valgte ut seks aktiviteter fra Blaus bok, som i tilpasset form ble utprøvd i en vg1klasse ved studieforberedende program i løpet av tre økter over en uke. Av hensyn til omfanget vil vi bare presentere og drøfte funn fra første og siste økt. ${ }^{3}$

Etter teoretiske og metodiske redegjørelser analyserer og drøfter vi funnene fra de to øktene hver for seg. Vi legger vekt på hva som skapte forutsetninger for utvikling av litterær kompetanse og hvilke delkompetanser som særlig ble tematisert. Avslutningsvis drøfter og vurderer vi undervisningsforløpet som helhet, med særlig hensyn til relevans for litteraturdidaktisk praksis.

\section{Litterær kompetanse}

Litterær kompetanse er et relativt flyktig begrep, opprinnelig lansert av Jonathan Culler (1975) som en litteraturvitenskapelig respons til den strukturalistiske lingvistikkens lingvistiske kompetanse. I Cullers tentative definisjon innebærer litterær kompetanse internalisering av en normbasert litterær grammatikk som aktiviseres i møte med litterære tekster. I Norden har både Bo Steffensen (2005) og Sylvi Penne (2013) brukt begrepet fiksjonskompetanse på lignende vis, mens Örjan Torell har videreutviklet Cullers begrep i en triadisk modell bestående av konstitusjonell kompetanse, performancekompetanse og literary transferkompetanse (Torell, 2001; Torell,

\footnotetext{
${ }^{2}$ Blau er «Professor of Practice» ved Teachers College, Columbia University, men har bakgrunn fra både litteraturvitenskapen som Milton-forsker og fra skriveforskningen gjennom The National Writing Project. Med sin kombinasjon av litteraturteoretisk, læringsteoretisk og konkret praktisk tilnærming til feltet er han en ledende figur i amerikansk litteraturdidaktikk. Han har også fått en viss utbredelse i Norge, gjennom anvendelse av hans modell for litterær kompetanse (Fodstad \& Gagnat, 2019; Fodstad \& Mortensvik, 2018), og gjennom formidling av konkrete undervisningsaktiviteter (Fjørtoft, 2014; Hove \& Solbu, 2017).

${ }^{3}$ Disse øktene er vektlagt fordi de representerer størst bredde med hensyn til skjønnlitterære delkompetanser, mens funnene fra den midterste økten delvis overlapper med de to øvrige. Ingen funn fra den midterste økten avviker signifikant fra eller tilfører noe vesentlig annet enn det vi presenterer her.
} 
von Bonsdorff, Bäckmann \& Gontjarova, 2002). I denne modellen handler litterær kompetanse om balanse mellom innlært evne til konvensjonsstyrt analyse av litterære tekster (struktur, komposisjon, fortelleteknikk, intrige, sjanger, figurativt språk etc.) og evnen til å knytte forbindelse mellom teksten og egne livserfaringer. Slik utvider Torell forståelsen av litterær kompetanse til ikke utelukkende å handle om konvensjoner, men også overføring mellom leserens «jeg» og tekstens "du». ${ }^{4}$

Leseren inntar altså en mer sentral plass i Torells modell enn i Cullers mer tekstautoritære beskrivelse av litterær kompetanse, og transferbegrepet utledes med utgangspunkt i Louise Rosenblatts transaksjonsteori (jf. Rosenblatt, 2005). Likevel posisjonerer Torell seg i opposisjon til den mer rendyrkede erfaringspedagogiske tradisjonen i Sverige. Fokuset på balanse mellom på den ene siden subjektorientert innlevelse og identifikasjon og på den andre siden analytisk og kritisk distanse er dessuten et aspekt man kan kjenne igjen fra en rekke andre leseforskere og didaktikere, selv om de ikke eksplisitt bruker begrepet litterær kompetanse. Judith Langers (2005) forestillingsbygging innebærer dialektikk mellom subjektivt og objektivt dominerte leserposisjoner. Det samme kan sies om Robert Scholes' ofte siterte beskrivelse av kompetent fiksjonslesning som «being able to place or situate a text, to understand it from the inside, sympathetically, and to step away from it and see it from the outside, critically» (Scholes, 1998, s. 130). En tilsvarende spenning finnes også hos Martha Nussbaum, som riktignok er opptatt av narrativ innlevelse, men som like fullt omtaler lesing av fiksjonstekster som en kombinasjon av «own absorbed imagining with periods of more detached (and interactive) critical scrutiny» (Nussbaum, 1995, s. 9).

I The Literature Workshop leder Sheridan Blaus teoretiske refleksjoner og praktiske eksempler frem til en modell for litterær kompetanse som i likhet med Torells består av tre komponenter. ${ }^{5}$ Blau kaller sine delkompetanser tekstuell literacy (prosessuell kunnskap), intertekstuell eller kulturell literacy (informasjonskunnskap) og performativ literacy (muliggiørende kunnskap) (Blau, 2003a, s. 203). Tekstuell literacy betyr evnen til å lese, analysere, fortolke og vurdere litterære tekster. Intertekstuell literacy innebærer kjennskap til tekster, sjangrer, historiske hendelser og lignende som kan bidra til forståelse av en gitt tekst. Performativ literacy refererer til den enkeltes evne til å møte litterære tekster som autonome og engasjerte lesere. Dette krever utholdende fokusert oppmerksomhet, vilje til å utsette konklusjoner, vilje til å ta risiko, toleranse for nederlag, toleranse for tvetydighet, paradokser og usikkerhet, intellektuell raushet og fallibilisme, ${ }^{6}$ samt metakognitiv oppmerksomhet.

\footnotetext{
${ }^{4}$ I norsk sammenheng har særlig Hallvard Kjelen vært inspirert av og tatt i bruk Torells kompetansemodell, først i doktoravhandlingen om ungdomsskolelæreres syn på litteraturundervisning (Kjelen, 2013) og senere i studier av lærerstudenters litterære kompetanse (Kjelen, 2014; 2015). I en kritisk læreplananalyse har også Fodstad (2013) tatt utgangspunkt i Torells modell.

${ }^{5}$ Blau presenterer også sentrale poeng i artikkelformat (jf. Blau, 2003b; 2011; 2014), men uten å tilføre vesentlig nye elementer sammenlignet med boken.

${ }^{6}$ Som erkjennelsesteoretisk begrep innebærer fallibilisme oppfattelsen av at absolutt sikkerhet eller allmenngyldighet er uoppnåelig for menneskelig erkjennelse.
} 
Blaus og Torells komponenter er delvis overlappende, men vi tar utgangspunkt i Blaus modell, ettersom den synes best egnet til vårt formål. For det første skyldes det at Torells konstitusjonelle kompetanse er statisk og vanskelig å operasjonalisere i analysesammenheng. Dessuten gjøres Torells Culler-inspirerte performancekompetanse mer finmasket hos Blau: tekstuell literacy innebærer evne til tekstintern lesing, forståelse, analyse og fortolkning av litterære tekster, mens intertekstuell literacy innebærer tekstekstern kjennskap til tekster, sjangrer, historiske hendelser og lignende forhold som påvirker forståelsen. Denne inndelingen finner vi analytisk hensiktsmessig. Enda viktigere i vår sammenheng er Blaus performative literacy, som særlig fremhever læringsstrategiske og metakognitive aspekter som mangler i Torells modell. ${ }^{7}$ Den største mangelen i Blaus modell er således at den ikke eksplisitt skiller ut literary transfer-kompetanse, men denne dimensjonen er til gjengjeld immanent i både performativ og intertekstuell literacy.

Ettersom undersøkelsen bygger på Blaus litteraturdidaktiske praksis, ligger det teoretiske grunnlaget også tett opp mot hans. I praksis vil det si et sosiokulturelt syn på læring med røtter hos Vygotskij (2001), hvor tanken utvikles gjennom språket og i sosialt samspill. I forlengelse av dette ligger også Lave \& Wengers (1991) idé om situert læring og deltakelse i praksisfellesskap. Særlig er Blaus litteraturundervisningssyn inspirert av Dewey, som i sin studie av kognitive prosesser trekker frem forvirring som nødvendig utgangspunkt for enhver tolkningshandling, og dermed også for å utvikle autonomi som fortolker (Dewey, 1991/1910, s. 11-13). Oppsummert ser vi altså på utvikling av litterær kompetanse som en prosess situert i språklig-sosiale fellesskap med utgangspunkt i litterære tekster som skaper forvirring og fortolkningsrom.

\section{Metode og materiale}

Studien er utformet som en kvalitativ kasusstudie. Forskningen er altså i hovedsak beskrivende og knyttet til et bundet og integrert system, i vårt tilfelle et praktisert undervisningsopplegg i en skoleklasse. Forskningsdataene er innhentet gjennom deltakende observasjon av hele elevgruppen og intervjuer med tre fokuselever. Deltakerne består av en vg1-klasse på studieforberedende utdanningsprogram ved en skole i Midt-Norge. Elevene har middels til høy norskfaglig kompetanse, basert på så vel observasjonsarbeidet og samtaler med norsklæreren deres. Vi forsøker å utforske og forstå både hvordan undervisningsopplegget var i den konkrete situasjonen, og hvordan kasuset gjennom naturalistisk generalisering kan tjene som relevant eksempel på hvordan litteraturdidaktisk praksis kan organiseres, samt hvilke konsekvenser en slik organisering kan ha.

\footnotetext{
${ }^{7}$ På dette punktet kunne det også vært mulig å ta utgangspunkt i Olle Nordbergs (2017, s. 49) firedelte modell, som inkluderer metakognitive aspekt, men ikke med like spesifikke underkategorier som Blau. Nordberg mangler dessuten Blaus skille mellom tekstuell og intertekstuell literacy.
} 
Observasjonens formål var å dokumentere hva som faktisk skjedde i undervisningen, samt å fange opp korte, spontane og ustrukturerte samtaler. Observatøren var selv deltakende som lærer i øktene, noe som ga innsikt i den sosiale situasjonen, fremsto mest mulig etisk forsvarlig (Hoel, 2000, s. 162) og gjorde situasjonen mest mulig naturlig for elevene (Tjora, 2017, s. 51). Til gjengjeld krevde dette at lærerobservatøren kombinerte ulike roller og oppgaver, og at observasjonsnotatene hovedsakelig ble gjort like i etterkant av observasjonen og etterfølgende intervjuer. Observasjonsnotatet ble strukturert etter henholdsvis beskrivelser/forklaringer og umiddelbare analyser og tolkninger. Dessuten inkluderte det notater om sosial kontekst, fysisk og materiell kontekst, helhetlig oppfatning av undervisningen, hva som var hensiktsmessig/ uensiktsmessig og hva som kunne forbedres.

Sentralt i undersøkelsen vår står elevers egne opplevelser av og erfaringer fra undervisningen. Derfor foretok vi semistrukturerte intervjuer med fokuselever umiddelbart etter hver undervisningsøkt. Det er disse intervjuene som utgiør hoveddataene i studien, mens observasjonsnotatene bidrar til å kontekstualisere intervjuutsagnene og vurdere hvorvidt de er i overensstemmelse med observasjonene. Hver intervjuguide inneholdt en informerende innledning, et åpent spørsmål om undervisningsøkten som helhet, en rekke spørsmål om opplevelsen av de enkelte læringsaktivitetene og til slutt en oppsummering med mulighet for oppklaringer. Intervjuene varte fra 15 til 25 minutter, ble tapet, og deretter transkribert til normalisert bokmål med anonymiserte navn. ${ }^{8}$ Både intervjutranskripsjoner og observasjonsnotater ble analysert $i$ en hermeneutisk frem- og tilbakeprosess mellom enkeltdeler og helhet. Slik ble de ulike læringsaktivitetene undersøkt hver for seg, men også i lys av den samlede økten, sosiale og fysiske kontekster og hele undervisningsforløpet. Materialet ble ikke kodet, men fortolket i lys av de teoretiske perspektivene som er redegiort for, og da særlig de enkelte aspektene i Blaus kompetansemodell.

Fokuselevene ble utpekt og spurt av klassens norsklærer, ettersom hun kjente elevene best. Utvalgskriteriene var at begge kjønn var representert, at fokuselevene hadde lite fravær og at de ikke representerte prestasjonsmessige ytterpunkter i norskfaget. Det lave antallet fokuselever setter store begrensninger for generalisering, men åpner til giengjeld for grundig informasjon om opplevelsene deres. Fokuselevene har ganske ulike forhold til faget generelt og skjønnlitterær lesing spesielt.

Nils er tospråklig, liker og mestrer lesing av både skjønnlitteratur og sakprosa, men sliter mer med skriving. Han leser mye, særlig romaner, både på norsk og engelsk, og sier han liker det fordi det gir ham opplevelser, grunnlag for refleksjon og nye perspektiv. Tolkning av skjønnlitteratur er også noe han stort sett opplever å mestre, men han mener det kan være vanskelig å forstå og sette seg inn i andres tolkninger.

Julie gir uttrykk for at norskfaget er interessant og viktig for fremtidig samfunnsdeltakelse. Særlig trekker hun frem «sosiale ting» som å kunne kommunisere og

\footnotetext{
${ }^{8}$ Intervjuguider og transkriberte intervju er tilgjengelige i Thomassen (2016).
} 


\section{A. Fodstad $\mathcal{E}$ M. M. Thomassen}

tolke, mens det hun liker best, er å lese og skrive skjønnlitterært. Hun «elsker å lese", både fordi det byr på opplevelser og fordi det får henne til å reflektere og få nye perspektiver. Tolkning av skjønnlitteratur er i utgangspunktet noe hun liker godt, selv om det kan være vanskelig å forstå tekster som krever at hun må «lese mye mellom linjene».

Pål strever med å si noe om hvordan han opplever norskfaget, men vi tolker ham dithen at han finner det nyttig selv om motivasjonen er laber. Han leser lite skjønnlitteratur og har kun lest én roman, i forbindelse med norskundervisningen semestret $i$ forveien. Særlig syns han arbeid med lyrikk er slitsomt, så det hender han gir opp og finner på det han omtaler som en tilfeldig tolkning. Pål syns det er vanskelig å svare på hvorfor vi arbeider med skjønnlitteratur i norskfaget, bortsett fra at det kan øke ordforrådet og enkelte ganger underholde.

\section{Undervisningsopplegget}

Undervisningsopplegget fordelte seg på tre økter i løpet av en uke, hvor hver økt varte mellom 60 og 80 minutter. Opplegget var utformet som et eksperiment, hvor vi ville undersøke hva som skjedde i undervisningssituasjonen og hvordan elevene opplevde det. Studiens eller de enkelte aktivitetenes hensikt ble ikke forklart for elevene eller tematisert gjennom refleksjonsøvelser.

Formålet med undervisningen var at elevene skulle øve på tekstuell, intertekstuell og performativ literacy ved å lese, tolke og vurdere lyriske tekster individuelt og kollektivt. Øktene vektla ulike aspekter ved litterær kompetanse, selv om prinsippene var gjennomgående. Første økt fokuserte spesielt på nærlesing og metakognisjon, mens siste økt særlig fokuserte på intertekstuelle og kontekstuelle forhold. Figur 1 og 2 viser skjematiske oversikter over henholdsvis første og siste økt, inkludert hvilke tekster som ble brukt. For å legge til rette for utforskende nærlesing, fortolkning og refleksjon innenfor tidsrammene våre, tok vi utgangspunkt i korte og betydningstette tekster. I tråd med Blaus prinsipper var lærerens rolle å legge til rette for elevenes utforskning og meningsskaping gjennom veiledning, utfordringer, spørsmål og nødvendige ordforklaringer.

\section{Analyse av første økt}

I den første leseøvelsen skulle elevene først studere Johan Grips dikt «Hentet» og rekke hånden i været når de mente de forstod det. Øvelsens hensikt er å gjøre elevene bevisst på hvordan de leser en litterær tekst, hva de forstår og sliter med å forstå og hvilke strategier de velger i møte med utfordringene de møter $\mathrm{i}$ jakt på forståelse. Observasjonsnotatene vitner om at elevene jobbet konsentrert, og allerede etter ett minutt var det en håndfull elever som var oppe med hånden. Intervjuene tyder på at elevene fant arbeidsmåten hensiktsmessig. Julie mener den var øktens mest interessante del, fordi den fikk henne til å reflektere over verdien av å lese samme tekst flere 


\begin{tabular}{|c|c|c|}
\hline Aktivitet & Varighet & Beskrivelse \\
\hline & $80 \mathrm{~min}$ & $\begin{array}{l}\text { Tekster i bruk } \\
\text { Johan Grip: «Hentet» (fra Enkle dikt, 2003) } \\
\text { Lina Undrum Mariussen: «Uten tittel» («en mandag i august er du en } \\
\quad \text { tom stol», fra Finne deg der inne og hente deg ut, 2011) }\end{array}$ \\
\hline Introduksjon, bli kjent & $20 \mathrm{~min}$ & $\begin{array}{l}\text { Bli kjent-lek, navneskilt, informasjon om prosjektet, samtale om } \\
\text { skjønnlitteratur og norskfagets formål }\end{array}$ \\
\hline $\begin{array}{l}\text { Tekstlesing og tanker om } \\
\text { hvordan man leser } \\
\text { skjønnlitteratur }\end{array}$ & $12 \mathrm{~min}$ & $\begin{array}{l}\text { Individuell lesing inntil } 3 \text { minutter, armen opp når de mente de forstod det } \\
\text { Parsamtale om tekstens mening, hvordan de kom frem til den, hvordan selve } \\
\text { leseopplevelsen var og hva de gjorde dersom det var ting de ikke forstod } \\
\text { underveis } \\
\text { Plenumsamtale om hva elevene mente var diktets mening, hvordan de kom } \\
\text { frem til den og hva de gjorde når de ikke forstod }\end{array}$ \\
\hline $\begin{array}{l}\text { Tre lesninger med notater, } \\
\text { spørsmål, samtale og } \\
\text { rangering av egen } \\
\text { forståelse }\end{array}$ & $\begin{array}{l}5 \mathrm{~min} \\
3 \mathrm{~min}\end{array}$ & $\begin{array}{l}\text { Individuell lesing med blyant, rangere egen forståelse fra } 0 \text { til } 10 \text { etter hver } \\
\text { lesing, notere ned merknader eller spørsmål til diktet, og etter tredje } \\
\text { lesning skrive en kort beskrivelse av hva som skjedde med forståelsen } \\
\text { gjennom de tre lesningene samt eventuelle spørsmål de fortsatt hadde til } \\
\text { diktet } \\
\text { Pause } \\
\text { Gruppesamtale (grupper på tre), med aktiv bruk av individuelle notater, om } \\
\text { hva som skjedde med forståelsen gjennom lesningene, diktets mening, } \\
\text { spørsmålene de hadde til det, til slutt ny individuell rangering av } \\
\text { forståelsen fra } 0 \text { til } 10 \\
\text { Plenumssamtale om leseeksperimentet med utgangspunkt i spørsmål om } \\
\text { hvor mange av elevene som vurderte forståelsen sin høyere etter hhv. } \\
\text { andre lesning, tredje lesning og gruppesamtalen, og hva dette ev. kunne } \\
\text { skyldes } \\
\text { Plenumssamtale hvor elevene måtte ta stilling til følgende påstand: «Lesing } \\
\text { er en prosess hvor man konstruerer mening eller komponerer en tekst. } \\
\text { Man kan si at lesing er som skriving: Vi behøver førsteutkast, revidering } \\
\text { og bearbeiding av teksten (mest i leserens hode). All god lesing er } \\
\text { gienlesing, slik all god skriving er gienskriving.» } \\
\text { Plenumsrefleksjon om hele økten }\end{array}$ \\
\hline
\end{tabular}

Figur 1. Oversikt over første undervisningsopplegg.

ganger. Pål syntes teksten var litt for enkel for formålet, mens Nils likte tidsbegrensningen på tre minutter. I den avsluttende plenumssamtalen var det mange muntlig aktive elever som gjerne ville dele sin forståelse. Flere av dem fremhevet at de oppdaget nye tekstelementer ved gjentakende lesing.

I den andre leseøvelsen skulle elevene, med utgangspunkt i et dikt av Lina U. Mariussen, gjennom både individuell nærlesing, gruppesamtaler og plenumsoppsummering, samt flere runder med vurdering av egen forståelse. Opplegget ble med noen tillempninger gjennomført i tråd med fremgangsmåten Blau (2003a, s. 36-42) skisserer: Først leser elevene diktet tre ganger individuelt og stille, med blyant. For hver lesning skal de legge merke til hva de finner interessant eller vanskelig å forstå og notere dette, samt rangere sin egen forståelse på en skala fra 1 til 10 . I fortsettelsen deler elevene sine forståelser og leseopplevelser i gruppesamtaler, før de foretar nok en runde med notater og rangering. Avslutningsvis gjennomgås funnene fra rangeringsøvelsen i plenum, før klassen må ta stilling til en påstand om lesing som prosess. Også her er formålet metakognitiv bevisstgjøring, altså å synliggjøre lese- og 


\begin{tabular}{|c|c|c|}
\hline Aktivitet & Varighet & Beskrivelse \\
\hline & $80 \mathrm{~min}$ & $\begin{array}{l}\text { Tekster i bruk } \\
\text { Karpe Diem: «Kunsten å være inder» (fra Glasskår, 2004) } \\
\text { Anne Bøe: «Sirkelrot» (fra Krigslogikkene, 2001) } \\
\text { «Prometevs og Pandora» (fra Michael Gibsen: Gresk mytologi, 1978) } \\
\text { Hallvard Notaker: «Terrorangrepet 11. september 2001» (snl.no) }\end{array}$ \\
\hline Introduksjon & $2 \mathrm{~min}$ & Lærerpresentasjon av opplegget \\
\hline Lesing med leserroller & $10 \mathrm{~min}$ & $\begin{array}{l}\text { Pararbeid med Karpe Diem-teksten, der den ene skulle være seg selv og den } \\
\text { andre skulle være Georg Brandes, kort lærerpresentasjon av Brandes og } \\
\text { hans tid, individuell lesing og tolkning med utgangspunkt i gitt rolle, } \\
\text { parsamtale om diktets mening } \\
\text { Plenumssamtale om diktets mening ut fra leserrollene, betydningen av } \\
\text { leserens bakgrunn, til slutt lærerrefleksjon over hvor historisk betinget } \\
\text { lesekompetansen er }\end{array}$ \\
\hline $\begin{array}{l}\text { Utprøving av hvordan } \\
\text { intertekstualitet } \\
\text { påvirker tolkningen av } \\
\text { en tekst }\end{array}$ & $\begin{array}{l}15 \mathrm{~min} \\
5 \mathrm{~min} \\
10 \mathrm{~min} \\
10 \mathrm{~min}\end{array}$ & $\begin{array}{l}\text { Individuell lesing med blyant tre ganger av Bøe-diktet, skriving om diktets } \\
\text { mening (med minst tre bevis), vanskelige passasjer, egen mening om det } \\
\text { man oppfatter som diktets tematikk, tefleksjoner over egen forståelse av } \\
\text { diktet } \\
\text { Individuell lesing av myte og leksikonartikkel, oppfordring til å notere ned } \\
\text { momenter de mente ville være relevante for diktet } \\
\text { Individuell gienlesing av Bøe-diktet, notering av spørsmål til diktet og } \\
\text { refleksjon over egen forståelse av det } \\
\text { Gruppesamtale om det elevene forstod og ikke forstod, argumentering for } \\
\text { egen forståelse ved bruk av bevis i teksten eller konteksten } \\
\text { Plenumssamtale om hva som skjedde med elevenes forståelse gjennom hele } \\
\text { leseprosessen, diskusjon om teksten mening, til slutt skulle eleven ta } \\
\text { stilling til følgende påstand: «Elever bør være produsenter og ikke } \\
\text { konsumenter av litterære tolkninger. Elever bør gjøre sine egne lesninger } \\
\text { av litterære tekster» }\end{array}$ \\
\hline Oppsummering & $3 \mathrm{~min}$ & Oppsummerende informasjon om forskningsprosjektet \\
\hline
\end{tabular}

Figur 2. Oversikt over tredje undervisningsopplegg.

tenkemåter samt hva litterær forståelse innebærer. Særlig vekt legges på nærlesing forstått som gjenlesing og forståelse som noe prosessuelt og uavsluttet. ${ }^{9}$

I intervjuene fremhever Nils og Pål arbeidsroen under det individuelle arbeidet, mens alle tre gir uttrykk for at de spesifikke instruksjonene var hjelpsomme. Intervjuene indikerer at gjentatte lesninger bidro til økt forståelse av diktet. Pål forstod det ikke ved første lesning, men opplevde økt forståelse gjennom de tre lesningene. Julie mente riktignok hun forstod diktet ganske godt allerede ved første lesning, men beskriver likevel en utvikling: «Du begynner å skape deg et bilde, men du har ingen sånne konkrete detaljer. De begynner du ikke å sette inn før du på en måte leser den andre gangen, for da har du på en måte grunnplata, så begynner du å plassere detaljene for å skape et bilde». Også Nils mener han økte forståelsen sin ved gjentatte lesninger, men han mener gjenlesning kan være problematisk dersom man forstår teksten ved første lesning, fordi det da kan erstatte tillit til egen forståelse med forvirring og usikkerhet. På dette punktet inntar Julie og Nils altså omvendte posisjoner:

\footnotetext{
${ }^{9}$ Her kan det selvsagt innvendes at det er en viss selvmotsigelse i å fremheve forståelse som noe uavsluttet og prosessuelt samtidig som den rangeres på en finitt skala. Metoden er slik sett prinsipielt problematisk, uten at dette ble tematisert i undervisningen.
} 
Mens Julie ser på gjenlesning som en mulighet til å videreutvikle og nyansere den første forståelsen, mener Nils at det snarere kan føre til økt forvirring. Når det gjelder rangeringen av egen forståelse, er de tre elevene delvis uenige. Også her er det Nils som er mest skeptisk til nytten. Pål var mer positiv til denne delen av forsøket, men syntes det var vanskelig å utføre. Julie mente rangeringen var interessant, og trekker det også frem i intervjuet etter andre økt, hvor hun savnet denne komponenten.

Under den påfølgende gruppesamtalen var engasjementet tilsynelatende stort. Både Nils og Pål mener samtalene bidro til økt forståelse, mens Julie i liten grad opplevde dette, siden hennes gruppe stort sett hadde samme tolkning. Likevel ser hun verdien av slike samtaler, fordi den kan tematisere «hvordan de kom fram til den meningen i forhold til meg, hvordan jeg kom fram til min», og at dette kan føre til at hun endrer eller i hvert fall nyanserer egen forståelse. Påls gruppe var preget av en viss uenighet, noe han trekker frem som en fordel, «med mindre man er veldig sånn kverulant da» - altså så lenge man er åpen for hverandres ulike tolkninger. For Nils var opplevelsen mer blandet, nettopp fordi han savnet denne åpenheten. Han trekker riktignok frem potensialet for nyansering og konsolidering av egen tolkning i møte med medelevenes. Samtidig opplevde han frustrasjon over at tolkningsuenighetene utartet til en konkurransepreget kamp om den riktige forståelsen, og til slutt også tvil om egen tolkning. Uenigheten forble uforløst, og han opplevde at de andre på gruppen var lite åpne for hans tolkning, og at det derfor heller ikke ble mulig å forhandle seg frem til en felles forståelse, som han selv ville foretrukket.

I den avsluttende plenumssamtalen vurderte mange elever forståelsen sin slik at den økte ved flere lesninger, og de trakk særlig frem det at de la merke til stadig flere detaljer i teksten. Også gruppesamtalen påvirket vurdering av egen forståelse $\mathrm{i}$ positiv retning for mange elever, særlig fordi de da ble utfordret av alternative forståelser, men flere trakk også frem muligheten for tolkningshjelp av medelever samt bedre grunnlag for å vurdere sin egen forståelse. Både observasjonene og intervjuene tyder på at refleksjon over egen forståelse var særlig hensiktsmessig. Julie er den som uttrykker det mest eksplisitt, idet hun fremhever nytten av å reflektere over hvordan og hvorfor man kommer frem til en viss tolkning.

Engasjementet var høyt da klassen diskuterte påstanden om lesing som prosess, og intervjudeltakerne uttrykte også interesse for emnet. Den første delen av påstanden at lesing er en meningskonstruerende prosess som minner om skriveprosessen fikk utbredt støtte både i klassesamtalen og intervjuene. Julie sammenligner første gjennomlesning med å lage tankekart, grunnstruktur og etter hvert ferdig tekst i en skriveprosess. Pål har samme synspunkt, om ikke like konkret formulert, mens Nils slutter seg til, men nyanserer påstanden: «... når du skriver, så er det din idé ..., men når du leser en tekst, så har du noe som allerede har blitt bygget opp. Det eneste du trenger å gjøre da, er å gå inn i teksten, og det kan kanskje være lettere enn å skrive en egen tekst, for da må du få opp konteksten selv». Denne nyanseringen av påstanden er verdt å merke seg, siden den kan forstås som en anerkjennelse av tekstens egenart i møte med leseren. Nils forstår litterær lesning som en forståelsesprosess i leseren, 


\section{A. Fodstad $\mathcal{G}$ M. M. Thomassen}

men samtidig legger teksten føringer som leseren må forholde seg til og en kontekst han må anerkjenne. På denne måten kan Nils' forbehold sees som et korrektiv til en undervisningsøkt som tilsynelatende la mer vekt på sosiokognitive prosesser enn selve den litterære teksten.

\section{Drøfting av første økt}

Funnene tyder på at gjenlesning var noe av det elevene opplevde som mest hensiktsmessig i den første økten, siden mange elever mente det gjorde dem oppmerksomme på detaljer i teksten. Med Blau (2003a, s. 211) kan vi si at gjenlesningen fungerte som trening $\mathrm{i}$ aspekter ved performativ literacy, slik som tålmodighet og vedvarende oppmerksomhet om teksten. Å lese hele eller deler av teksten flere ganger økte dessuten - om enn i varierende grad - elevenes forståelse. Funnene indikerer at oppmerksomhet om detaljer gjennom flere lesninger muliggjorde en hermeneutisk fortolkningsprosess, hvor del og helhet ble undersøkt i lys av hverandre. Gjenlesningen la dermed til rette for selvstendig arbeid med analysebasert tolkning - en sentral del av skjønnlitterær kompetanse (Blau, 2003a, s. 101-103). Ved å gjøre tolkningen prosessbasert legges det til rette for andre aspekter ved performativ literacy, slik som å utsette konklusjoner og tolerere usikkerhet. Gjenlesningen legger dessuten opp til en varig oppmerksomhet om teksten, ikke ulikt den man forbinder med nykritikkens nærlesningsprinsipp, og nettopp dette tekstlige fokuset er hos Blau (2003a, s. 196) et viktig premiss for litterær kompetanse.

Praksisen med instruert gjenlesning var likevel ikke uproblematisk. Flere elever uttrykte skepsis til nytten i tilfeller hvor man mener å ha forstått teksten allerede ved første lesning - et synspunkt som underbygges av at enkelte elever brukte kort tid på denne delen av opplegget. Innvendingen er forståelig, ettersom det kan synes meningsløst å lese på nytt om man ikke ser verdien av det. Teksten kan rett og slett ha vært for lett for enkelte, og det vil alltid være en praktisk utfordring å finne tekster som oppleves som autentiske, men likevel overkommelige, problem for en sammensatt gruppe. Den pålagte gjenlesningen har også et mekanisk preg som kan virke forstyrrende i utforskningen av teksten. Samtidig kan innvendingen sees som uttrykk for manglende vilje til å utsette konklusjoner eller evne til å drive tolkningsprosessen videre. Med Skaftun (2009, s. 86-88) kan man spekulere i om disse elevene er tilstrekkelig åpne for å undersøke tekstens diskursive livsverden. Når for eksempel Nils forteller om økt forvirring gjennom flere lesninger, tyder det på at videre undervisning bør vise ham hvordan han kan tolerere usikkerhet og forvirring i arbeid med skjønnlitteratur. I perioder kan slik undervisning også innebære leseinstrukser som virker mekaniske eller kunstige, slik som denne øktens fokus på gjenlesning.

Funnene tyder også på at samtale om tekst er en hensiktsmessig arbeidsmåte for å utvikle litterær kompetanse. I enkelte tilfeller fikk elever hjelp av medelever til å forstå tekstelementer de ikke forstod på egenhånd (jf.Vygotskij, 2001, s. 166-167). Det som først og fremst kommer frem, er imidlertid samtalens mulighet til økt forståelse 
gjennom formulering og underbygging av egen tolkning, tilgang til andres tolkninger, refleksjon over tolkningsmangfold og vurdering av ulike tolkningers holdbarhet. I forlengelse av dette finner vi også poenget Julie var inne på i intervjuet, nemlig samtalen som utforsking av hvordan medelever konstituerer lesningene sine. Samtaleformen synes å muliggiøre arbeid med performativ literacy særlig med hensyn til toleranse for betydningsmangfold og det Blau (2003a, s. 214) kaller intellektuell raushet og fallibilisme. Det virker også som om samtaleformen la til rette for at elevene sammen kunne utforske diktet og etablere en sosial praksis for læring (Lave \& Wenger, 1991, s. 47). En slik praksis kan sees som eksempel på det Wayne Booth (1988, s. 70-77) i litteraturspesifikk sammenheng betegner som conduction, til forskjell fra induksjon og deduksjon. Slik tenkning er utledet fra samtalebasert forhandling med andre lesere og gir derfor kunnskap som alltid er provisorisk, siden litterære meninger og vurderinger baserer seg på tidligere litterære erfaringer som nødvendigvis endres over tid.

Både gjenlesning og samtale om tekst henger sammen med det tredje tydelige funnet etter første økt, nemlig at arbeidsformen så ut til å utfordre elevene til metakognisjon. For Blau er dette et avgjørende aspekt ved performativ literacy, og han mener ikke det står i motsetning til fokusert arbeid med selve den litterære teksten. Å overvåke og styre egen leseprosess er viktig for å vite hva man må giøre for å forstå en gitt tekst, og dermed også en indikator for litterær kompetanse (Blau, 2003a, s. 214). Av intervjudeltakerne er det særlig Julie som tematiserer dette, siden hun er opptatt av hvordan ulike tolkninger blir til, og hvordan de ulike tolkningenes betingelser og nyanser kan utforskes i samtale. Men også elevenes vilje til å dele leseerfaringer og vurderinger av egen forståelse i plenumssamtalen tyder på at undervisningen i forkant skapte muligheter for metakognitiv refleksjon.

\section{Analyse av siste økt}

I første øvelse jobbet elevene parvis med «Kunsten å være inder» av Karpe Diem, men med en spesiell vri. Én skulle forsøke å forstå og tolke teksten med utgangspunkt i sin egen livsbakgrunn, mens den andre skulle forsøke å gå inn i rollen som Georg Brandes, for å prøve ut i hvilken grad og hvordan han, hypotetisk sett, ville forstått teksten. Økten ble innledet med en presentasjon av Brandes, slik at elevene hadde forutsetninger for rollespillet. Etter parøvelsen fulgte plenumssamtale om hvordan leserens bakgrunn virker inn på forståelsen, og hvor historisk betinget lesekompetanse er.

Hensikten var å bevisstgjøre elevene om hvordan den enkeltes erfaringer påvirker tekstforståelsen, samt at kunnskap om konteksten den har blitt til og virket i er relevant i møte med teksten. Observasjonene tydet på at enkelte elever fant det utfordrende å innta Brandes-rollen, men plenumssamtalen ble likevel preget av stort engasjement. Synspunktene som kom frem, var at tekstens kontekst var viktig for forståelsen og at språket i teksten var preget av sin samtid, hvilket ville bydd på problemer for Brandes, selv med hans litterære ekspertise. Intervjudeltakerne mener 


\section{A. Fodstad E M. M. Thomassen}

øvelsen fikk dem til å reflektere over leserbakgrunnens og kontekstens betydning. Alle tre mener det ville vært utfordrende for Brandes å forstå teksten, og de trekker særlig frem behovet for å kjenne til den aktuelle kulturelle og politiske konteksten. Pål peker dessuten på at tekstens ironiske modus ville vært uforståelig for Brandes.

Den neste aktiviteten var eksplisitt rettet mot hvordan intertekstuelle forhold kan påvirke tolkningen av en tekst. Som i hoveddelen av første økt fikk elevene også her utlevert et dikt, Anne Bøes "Sirkelrot» (2001). Dette skulle de lese tre ganger individuelt, for så å skriftlig formulere diktets mening med bevis fra teksten. ${ }^{10}$ Deretter fulgte individuelt arbeid med to sakprosatekster som var egnet til å påvirke forståelsen av diktet, før de skulle gienlese diktet. Så fulgte gruppesamtale om elevenes forståelse av diktet, med bevisføring fra teksten eller konteksten, før avsluttende plenumssamtale om hvordan elevenes forståelse av diktet endret seg gjennom prosessen. Her skulle de også ta stilling til en påstand om at elever heller bør være produsenter enn konsumenter av litterære tolkninger.

Alle intervjudeltakerne fant arbeidsmåten hensiktsmessig. Både Pål og Julie mente det var enkelt å forstå diktet allerede ved første lesning, og at det handler om 9/11-terroren. "[D] et var ikke så mye som var skrevet mellom linjene», mente Julie, mens Pål la merke til at diktet var skrevet like etter $9 / 11$, noe som gjorde at han søkte bekreftelse snarere enn utforskning. Nils falt ikke ned på denne forståelsen like tidlig, men i løpet av andre gjennomlesning. Gjennom intervjuet uttrykker han hvordan den gjentatte lesningen og påvirkningen fra sakprosatekstene gradvis ga ham dypere forståelse for diktet:

... når jeg leste diktet uten å ha lest om Pandora, så tenkte jeg at det var krig, og at det var USA eller en annen stormakt som angriper et hvilket som helst fattig land og giør det verre, men når du liksom leser om Pandora, at hun finner håp $\mathrm{i}$ bunn av boksen, og at hun lukker igjen, så fikk jeg en sånn følelse av at diktet hadde en annen betydning. At det her skjer, men at det er håp.

At Nils ikke forstår diktet like fort som de to andre, gjør også at han synes åpnere for å utforske mulige betydninger, og at myten om Pandora derfor får spille en sentral rolle $i$ tolkningen hans. Han uttrykker eksplisitt at de som mener diktet var helt konkret og opplagt «sikkert ikke har satt seg nok inn i det» til å få en dypere forståelse. Basert på utsagnet ovenfor virker det som om denne «dypere» forståelsen innebærer en viss grad av abstraksjon. Til tross for at Nils skiller seg ut på dette punktet, opplevde også de to andre økt forståelse. For Pål sin del innebærer dette på den ene siden å få kjennskap til konkrete uttrykk som «å åpne Pandoras eske», og på den andre siden en mer helhetlig forståelse av diktet med «mer bevis» og «større sammenheng». Julie har en

${ }^{10}$ Textual evidence er et sentralt begrep hos Blau, og vi har her oversatt det med «bevis», selv om det ikke er helt treffende, siden det gir mer bastante assosiasjoner enn den engelske originalen. Når vi i fortsettelsen snakker om «bevis» og «bevisføring», skal det altså forstås slik at tolkning og forståelse er underbygget av tegn eller indisier i teksten, ikke ugjendrivelige bevis. Blau kobler dessuten "evidentiary reading» til hermeneutikkens frem-og-tilbake-pendling mellom del og helhet underveis i fortolkningsprosessen (jf. Blau 2003a, s. 75-76). 
lignende fremstilling av sin forståelsesprosess: «Det blir som når du på en måte leser bare for å få et overblikk da, og så begynner du å plassere inn detaljene etterpå». Julies prosessrefleksjon er lite spesifikk, og den tar heller ikke opp de fortolkningsmessige konsekvensene av å tilføre visse sakprosatekster midt i leseforløpet. Dette siste vil vi komme tilbake til.

Observasjonen tydet på at gruppesamtalen ble gjennomført med engasjement, men at enkelte grupper så seg ferdige så snart alle hadde presentert sin lesning, uten videre drøfting. Intervjuet med Pål underbygger dette, ettersom alle på gruppen hans mente diktet handlet om terror, både fordi diktet var såpass konkret og fordi den ene sakprosateksten spesifikt handlet om 9/11-terroren. Pål sier ingenting som åpner for en annen tolkning eller stiller spørsmål ved å la en lærerutplukket artikkel så entydig bekrefte riktig tolkning. Han mener likevel at samtalen kunne blitt mer interessant om de hadde vært mer kritiske og "spurt hverandre hvorfor vi mente det var terror", slik at de kunne fått i gang en diskusjon. Både Julie og Nils mener de hadde større utbytte av samtalen. Julie sier hun fikk innsikt $i$ andres meninger i en gruppe hvor det både var enighet og uenighet, men hvor de drøftet seg frem til en felles forståelse. For Nils bidro samtalen fordi den "fikk sånne småting fikset på», men også fordi relativt like lesninger ble nyansert i lys av hverandre og dermed utfordret forståelsen hans.

I den avsluttende plenumssamtalen ga flertallet uttrykk for at de hadde fått bedre og/eller dypere forståelse for diktet etter å ha lest artikkelen og myten. I samtale om diktets mening var det flere eksempler på at elever anvendte bevis fra teksten for å underbygge tolkningen sin. Bevisene var overveiende knyttet til tematikk, i liten grad til form eller kontekst, selv om tolkningene hadde åpenbare kontekstuelle premisser. Påstanden om at elever bør være produsenter heller enn konsumenter av tolkninger, fikk bredt bifall i klassen, men flere elever poengterte at man må kunne begrunne tolkningen sin.

De tre intervjudeltakerne var også enige i påstanden. Disse fikk dessuten servert to supplerende og gjensidig motstridende påstander, som det ikke ble tid til å drøfte i klasserommet: 2) «Det finnes kun én riktig tolkning av et dikt (og det er lærerens tolkning)». 3) "Alle lesninger av et dikt er riktige. Det er mine egne opplevelser og følelser rundt diktet som er viktige og som gjør en tolkning riktig.» De to påstandene kan sees som ytterpunkter i et tolkningskontinuum fra autoritetshegemoni til leseranarki. Gitt undervisningsoppleggets design, elevenes leserroller, samt den første påstanden, er det ikke overraskende at de tar avstand fra påstand 2 og overveiende er enige i påstand 3. De nyanserte imidlertid, og mener det kan finnes flere tolkninger av et dikt, at vi må verdsette ulike meninger og kritisk tenkning (Nils), og at vi kan lese den samme teksten ulikt, siden vi er ulike mennesker med forskjellige erfaringer (Julie og Pål). De åpner altså opp for betydningsmangfold med utgangspunkt i ulike lesererfaringer, men supplerer også med utsagn som peker mot litteraturens egen flertydighet. Nils påpeker for eksempel at «det kan være så mye som står mellom linjene», mens Pål mener «man kan tenke veldig mye ut av et maleri og et dikt». 


\section{A. Fodstad E M. M. Thomassen}

Alle tre er opptatt av at enhver leser har rett til sin tolkning, men at denne samtidig må kunne underbygges av tekstlige funn. Pål mener man må klare «å argumentere for det» ved hjelp av «bevis i teksten». Julie mener i utgangspunktet at ulike tolkninger må respekteres, ettersom ulike lesere har ulike erfaringer, bakgrunner og synspunkter. Samtidig avviser hun at en hvilken som helst tolkning kan støttes om den ikke ledsages av argumentasjon basert på tekstlige forekomster. Også Nils er opptatt av at tolkning må støttes av "grundige argumenter». Dette underbygger han med at tolkningen må kunne belegges med funn i teksten, men også at det er slik den kan giøres gyldig for andre. Egne opplevelser og følelser «er kanskje riktig for $d e g$, men du kan ikke liksom sette det som grunnlag for at det skal være riktig for alle sammen». Uten selv å bruke ordet, peker Nils på at fortolkning er et intersubjektivt anliggende, og at tolkningers holdbarhet må kunne tåle utprøving i tolkningsfellesskap.

\section{Drøfting av siste økt}

Både observasjonene og intervjuene tyder på at undervisningen la til rette for elevenes refleksjon over leserens bakgrunn, tekstens kontekst og til en viss grad også intertekstuelle forhold - og hvilken betydning disse aspektene har når man leser og skaper mening i møte med skjønnlitterære tekster. Med Blau (2003a, s. 206-208) kan vi si at opplegget la til rette for utvikling av intertekstuell eller kulturell literacy, forstått som informasjonskunnskap. Den innledende rollelesingen utfordret elevene til å reflektere over betydningen av kontekstuell bakgrunnskunnskap i møte med en tekst. Blau (2003a, s. 207) mener leseren i møte med tekster fra fjerne tider eller kulturer bør innta rollen som etnograf, som forsøker å forstå en kultur både med informantenes innenfraperspektiv og ens eget observasjonsblikk utenfra. Rollelesingen forsøkte å få frem dette poenget for elevene, og så vel observasjonen som intervjuene tyder på at det i stor grad lykkes.

Den andre aktiviteten synes, i likhet med andre aktivitet i første økt, å ha lagt til rette for undersøkende, tekstnært og prosessorientert tolkningsarbeid, hvor elevene fikk trening $\mathrm{i}$ å konstruere gjennomtenkte lesninger basert på tekstlige funn. Gjennom arbeidet fikk elevene øve seg på hvordan man går frem for å skape mening av en litterær tekst (tekstuell literacy), hvordan denne meningen blir til i en prosess som krever varig konsentrert individuelt arbeid, toleranse for flertydighet og intellektuell raushet i samarbeid med andre (performativ literacy), men også å få innsikt i tekster som på ulike vis er særlig relevante for meningsskapingen (intertekstuell literacy). Intervjudeltakerne gir uttrykk for at kombinasjonen av grundig, gjentatt nærlesing og tilføring av kontekstuelt relevante sakprosatekster førte til økt forståelse og mer holdbare tolkninger. Kunnskap om diktets historiske og sosiale kontekst, i dette tilfellet terrorangrepet $9 / 11$, påvirket elevenes forståelse. Mer generelt kan man si at innsikt i tekster som på et eller annet vis står i intertekstuelt forhold til den skjønnlitterære teksten, er sentralt for forståelsen av den. 
På dette punktet må det imidlertid tas forbehold. Både observasjonen og intervjuene tyder på at artikkelen om 9/11 bidro til lite utforskende lesninger, fordi mange elever etter å ha lest artikkelen mente de hadde forstått diktet. Påls syn på gruppesamtalen som unødvendig bekrefter poenget. Med et begrepspar fra Judith Langer (2011, s. 26-35) kan vi si at artikkelen fikk mange elever til å fastholde et referansepunkt giennom lesningen sin, heller enn å utforske nye mulighetshorisonter, og dette er en lesemåte som i liten grad ivaretar skjønnlitteraturens betydningspotensial og tolkningsrom. Artikkelen fungerte som en tolkningsnøkkel på en måte som gjorde at diktet ble lest som virkelighetsrepresentasjon, snarere enn fiksjon, og slik sett bidro den til å forsterke det problemet vi innledningsvis så at mange forskere peker på. Hvordan kunne dette vært unngått, eller kanskje til og med utnyttet i undervisningen? Aktiviteten kunne i større grad lagt til rette for refleksjon over forholdet mellom diktet og verden, teksten og konteksten. Dette burde da også innebære tematisering av at konteksten er tekstbasert, og ikke minst at den er konstruert av tilgang til og utvalg av visse tekster.

Dermed er vi ved et punkt hvor Blaus begrep intertekstuell literacy blir problematisk. Det fokuserer hovedsakelig på kulturell kompetanse gjennom kjennskap til relevante tekster, altså en tekstfundert kunnskap om kontekst. Som litteraturteoretisk begrep er imidlertid intertekstualitet sammensatt og i visse tilfeller svært vidt definert. Det kan dekke alt fra åpenbare allusjoner, via bruk av konkrete tekstforelegg (Genette, 1997), til en generell tekstteori med utgangspunkt i Bakhtins intersubjektive dialogisme (Kristeva, 1980). Felles for disse svært ulike forståelsene av intertekstualitet er at det dreier seg om hvordan en teksts mening påvirkes av andre tekster. Dette fikk også elevene oppleve i vårt konkrete forsøk. Det som imidlertid savnes, er en bevissthet om hvilke forutsetninger denne meningspåvirkningen hviler på, hvilken mening den legger til rette for, og hvilke meninger den eventuelt $i k k e$ får oss til å utforske. Verken observasjonene eller intervjuene tydet på at slike mer grunnleggende hermeneutiske og epistemologiske sider av intertekstualitetsbegrepet inngikk i elevenes refleksjon over egen tolkningsprosess. Dette kan skyldes at læringsaktiviteten i liten grad la til rette for slike refleksjoner, hvilket igjen kan skyldes at perspektivet er underkommunisert i Blaus intertekstuelle delkompetanse noe som er påfallende med tanke på hvor sentralt metakognitiv bevissthet står i kompetansemodellen hans. Som både internasjonale (Langer, 1995; Nussbaum, 1995; Scholes, 1998) og nordiske (Nordberg, 2017; Penne, 2013; Skaftun, 2009) forskere har understreket, trenger elevene trening i å gå inn og ut av fiktive verdener. Med utgangspunkt i funnene fra denne undervisningsøkten vil et mulig supplement være at de trenger å gå inn og ut av ulike tekster som på et eller annet vis er satt i sammenheng - på en måte som minner om, men også videreutvikler Judith Langers (2011, s. 16-21) leserposisjoner i eksplisitt intertekstuell forstand: Elevene trenger trening $\mathrm{i}$ å tre inn i ulike forestillingsverdener som på et eller annet vis er koblet sammen, bevege seg rundt i dem hver for seg, tre ut av dem for å revurdere forståelsen både av den ene forestillingsverdenen i seg selv og i sammenheng med de andre, og tre ut for å objektivere leseropplevelsen, inkludert det intertekstuelle 
aspektet av den. ${ }^{11}$ Dette ville innebære en videreutvikling av Blaus intertekstuelle literacy på et vis som ivaretok også den metakognitive dimensjonen.

\section{Oppsummerende drøfting}

Etter endt norskfaglig opplæring forventes det at elevene skal kunne lese, forstå, tolke, vurdere og engasjere seg $\mathrm{i}$ et mangfold av tekster, inkludert skjønnlitterære. Med utgangspunkt i Blaus syn på litteraturundervisning skal den både fostre litterær kompetanse som sådan og tolkningsautonomi, kritisk tenkning og demokratisk deltakelse i videre forstand. Med henvisning til Robert Scholes knytter Blau (2003a, s. 204) den varige, fokuserte oppmerksomheten om teksten ikke bare til tekstuell literacy, men også til kritisk tenkning i mer generell forstand, med utgangspunkt i spørsmål som: Hvilke fakta har vi? Hvilke slutninger gir de grunnlag for? Hvilken verdi har funnene? Dermed er det viktig å undersøke hvordan og i hvilken grad ulike didaktiske praksiser legger til rette for at elevene får mulighet til å utvikle en slik kompetanse. Dette har vi forsøkt å gjøre ved å analysere konkrete undervisningsopplegg, ulike «litteraturlaboratorier», med hensyn til hvilke forutsetninger de skapte for utvikling av litterær kompetanse.

Oppsummerende kan vi si at undersøkelsen særlig har utforsket tre aspekter ved skjønnlitterær lesning: hvordan forståelsen utvikler seg gjennom tolkningsprosessen, hvordan forståelsen preges av leserens bakgrunn og kunnskap, samt hvordan forståelsen av én tekst kan påvirkes av andre tekster. Disse aspektene har ikke bare blitt utforsket i analyse og drøfting av funnene, men inngår også som en del av selve materialet, ettersom læringsaktivitetene eksplisitt har tematisert dem. I lys av Blaus kompetansemodell innebærer dette at utvikling av ulike dimensjoner ved performativ literacy har stått sentralt i hele forsøket, mens tekstuell literacy særlig var sentralt i første økt og intertekstuell literacy i siste.

Videre har analysen av materialet identifisert sju aktiviteter som ser ut til å kunne bidra til utvikling av performativ literacy: konsentrert nærlesing, gjenlesing, notatskriving, gruppesamtaler, plenumssamtaler, bevisføring og metakognitiv refleksjon. Konsentrert nærlesing er en hermeneutisk dyd tett forbundet med evnen til varig fokusert oppmerksomhet, vilje til å utsette konklusjoner og toleranse for usikkerhet og flertydighet. Dette henger også tett sammen med gjenlesninger av samme tekst, en strategi som erfarne lesere benytter mer eller mindre ubevisst, men som mindre erfarne lesere gjerne må gjøres oppmerksomme på og til en viss grad styres mot. Tvungne gjenlesninger har riktignok noe kunstig over seg, og kan i noen tilfeller fremstå overflødig, men fungerer som en bevisstgjøring av hvordan manglende forståelse kan overvinnes og en nyansert forståelse vokse frem. I denne prosessen er dessuten blyanten et viktig

\footnotetext{
${ }^{11}$ Den intertekstuelle dimensjonen er for så vidt til stede i Langers fjerde posisjon, hvor hun nevner «literary elements and allusions» og beskriver hvordan leseren kan «become aware of why a particular author or piece holds significance for us», men dette nevnes en passant, og er ikke rettet mot eksplisitt intertekstuell lesemåte eller undervisning (Langer, 2011, s. 20).
} 
redskap, siden notater (inkludert spørsmål, understrekninger, tegninger og figurer) utvikler tanken gjennom språket samt medierer lesererfaringen, så den giøres tilgjengelig for etterfølgende refleksjon over prosessen. Et vesentlig verktøy for denne refleksjonen er gruppesamtalen, som også ser ut til å utvikle elevenes tekstforståelse, delvis fordi de inngår i praksisfellesskap hvor uklarheter og misforståelser kan løses, men særlig fordi dette praksisfellesskapet gir elevene tilgang til ulike tolkninger, samt rom for å for å drøfte tolkningers premisser, tankerekker og holdbarhet. Slike gruppesamtaler er derfor egnet til å utvikle deler av performativ literacy som særlig er knyttet til det å ta risiko, tolerere nederlag og utvikle intellektuell sjenerøsitet og fallibilisme. En ytterligere utvidelse av praksisfellesskapet forutsetter også plenumssamtaler, hvor både tolkningsmangfold og risiko for nederlag økes ytterligere. Sentralt i begge samtaleformene står drøfting og argumentasjon basert på bevisføring, altså en toleranse for flertydighet og tolkningsmangfold som holdes innenfor grensene av det som kan underbygges av faktiske funn i teksten. Intervjuene tyder på at denne dimensjonen er særlig viktig å utvikle, ettersom elevene gir uttrykk for særdeles romslige syn på individuelle fortolkninger og den enkelte lesers rett til å legge egne opplevelser og følelser inn i teksten, samtidig som alle de tre intervjudeltakerne er opptatt av tekstbasert bevisføring. Endelig peker metakognitiv refleksjon seg ut som en viktig komponent i utvikling av performativ literacy. Særlig tydelig var dette i den første økten, hvor elevene ble utfordret til å overvåke og vurdere egen leseprosess og forståelse. I den siste økten, derimot, kunne kanskje en mer eksplisitt metakognitiv tilnærming lagt grunnlag for utvikling av en mer omfattende intertekstuell kompetanse.

Funnene er i seg selv ikke oppsiktsvekkende, men bekrefter tendenser i andre nyere studier om potensialet i utforskende, problemorientert litteraturundervisning (Gourvennec, 2017; Sønneland, 2019). Samtidig foreslår vi her å supplere de åpne leseinstruksene disse studiene tar utgangspunkt $i$, med mer detaljert fasilitering av elevenes møter med skjønnlitteraturen - eksplisitt rettet mot utvikling av performativ literacy. I tillegg foreslår vi en videreutvikling av Blaus intertekstuelle literacy hvor forutsetningene for de intertekstuelle koblingene i enda større grad tematiseres, og hvor man særlig fokuserer på elevenes evne til å objektivere selve tekstutvalget og tolkningsgrunnlaget det utgjør.

Studiens omfang er beskjedent, hvilket innebærer begrensede generaliseringsmuligheter. Først og fremst er den derfor å anse som en kime til videre undervisningsmetodisk eksperimentering med tilhørende systematisk utforsking-fortrinnsvis i samarbeid mellom lærere og forskere, enten som kasusundersøkelser eller aksjonsstudier.

Avslutningsvis bør det påpekes at med fokus på læringsaktiviteter risikerer de litterære tekstene å havne i bakgrunnen. Dette kan virke problematisk, ettersom selve skjønnlitteraturen burde være det opplagte sentrum i en didaktikk for utvikling av litterær kompetanse. I verste fall gjør designet at hovedsaken i litteraturundervisningen reduseres til et redskap for å bedrive undervisningsmetodisk utforskning. Problemet er vanskelig å unngå uten at variablene blir for mange. Samtidig er det paradoksalt nok slik at både Blaus litteraturdidaktiske tanker og de aktivitetene vi baserer 
undersøkelsen vår på, er svært tekstnære. Betegnende er det i så måte at når elever fant enkelte aktiviteter lite hensiktsmessige, fremsto tekstutvalget som en viktig årsak, for eksempel ved at det ikke åpnet opp for nok usikkerhet eller flertydighet. Selv om dette aspektet har vært lite berørt i undersøkelsen vår, vitner den altså om at selve den litterære teksten er og bør være premissleverandør for læringsaktivitetene.

\section{Forfatteromtale}

Lars August Fodstad er førsteamanuensis i nordisk litteratur ved NTNU, hvor han både arbeider med litteraturvitenskap og litteraturdidaktikk. Spesialfeltet er det moderne gjennombrudds litteratur, og da særlig Kiellands forfatterskap, men han har også publisert artikler om Ibsen, Garborg, Iunker og litteraturdidaktiske emner.

Maja Myhre Thomassen er lektor med tilleggsutdanning ved Sortland videregående skole. Gjennom masterstudiet spesialiserte hun seg i litteraturdidaktikk. Som styremedlem i Landslaget for norskundervisning jobber hun også med fagpolitiske spørsmål.

\section{Litteratur}

Berge, K. L. (2005). Skriving som grunnleggende ferdighet og som nasjonal prøve - ideologi og strategier. I A. J. Aasen \& S. Nome (Red.), Det nye norskfaget (s. 161-188). Bergen: LNU/Fagbokforlaget.

Blau, S. (2003a). The Literature Workshop. Teaching Texts and Their Readers. Portsmouth, NH: Heinemann.

Blau, S. (2003b). Performative Literacy. The Habits of Mind of Highly Literate Readers. Voices from the Middle, 10(3), 18-22. Hentet fra https:/secure.ncte.org/library/NCTEFiles/Resources/Journals/VM/ 0103-march03/VM0103Performative.pdf?_ga=2.75696592.452737486.1585389856-1362657340. 1585389856

Blau, S. (2011). Fostering Authentic Learning in the Literature Classroom. I J. O. Milner \& C. A. Pope (Red.), Enganging American Novels. Lessons from the Classroom (s. 3-17). Urbana, IL: NCTE.

Blau, S. (2014). Literary Competence and the Experience of Literature. Style 48(1), 42-47. Hentet fra https:// www.jstor.org/stable/10.5325/style.48.1.42

Bøe, A. (2001). Krigslogikkene. En diktpamflett. Oslo: Gyldendal.

Culler, J. (1975). Structuralist Poetics. Structuralism, Linguistics and the Study of Literature. London: Routledge.

Dewey, J. (1991). How We Think. New York: Prometheus Books. (Utgitt 1910).

Fjørtoft, H. (2014). Norskdidaktikk. Bergen: Fagbokforlaget.

Fodstad, L. A. (2013). Litteratur uten form? Om læreplanens mål for eldre litteratur på ungdomstrinnet. I D. Skjelbred \& A. Veum (Red.), Literacy i lceringskontekster (s. 55-65). Oslo: Cappelen Damm Akademisk.

Fodstad, L. A. \& Gagnat, L. H. (2019). Forestillinger om litterær kompetanse blant norsklærere i videregående skole. Norsklceraren, 17. desember 2019. Hentet fra https://www.norskundervisning.no/nyheter-og-artikler/ forestillinger-om-litterr-kompetanse-blant-norsklrere-i-videregende-skole

Fodstad, L. A. \& Mortensvik, A. (2018). Øvelser i empati og kulturell tilgang. Avgangselevers legitimering av arbeid med eldre skjønnlitteratur i videregående opplæring. Acta Didactica Norge 12(3). https://doi. org/10.5617/adno.6149

Genette, G. (1997). Palimpsest. Literature in the Second Degree. Lincoln, NE: University of Nebraska Press.

Gourvennec, A. F. (2017). "Det rister litt $i$ hjernen»; En studie av møtet mellom høytpresterende elever $i$ videregående skole og litteraturfaglig praksis (Doktoravhandling, Universitetet i Stavanger). Hentet fra http://hdl.handle. net/11250/2466694

Grip, J. (2003). Enkle dikt. Oslo: Cappelen.

Hoel, T. L. (2000). Forskning i eget klasserom. Noen praktisk-metodiske dilemma av etisk karakter. I Nordisk pedagogikk, 20(2), 160-170. 
Johansen, M. B. (2015). «Jeg har forstået den sådan, at den ikke skal forstås» - når 6.A. læser Franz Kafka. Acta Didactica Norge, 9(1). http://dx.doi.org/10.5617/adno.1391

Karpe Diem. (2004). Kunsten å være inder. I Glasskår. Hentet fra https://www.lyricsbox.com/karpe-diemkunsten-å-være-inder-lyrics-jllxjnd.html

Kjelen, H. (2013). Litteraturundervisning $i$ ungdomsskulen. Kanon, danning og kompetanse (Doktoravhandling, Norges teknisk-naturvitenskapelige universitet). Hentet fra http://hdl.handle.net/11250/244244

Kjelen, H. (2014). Litterær kompetanse hos nye lærarstudentar. Norsklceraren, 2(14), 56-66. Hentet fra https://static1.squarespace.com/static/5d00b418d9cad80001fc3882/t/5d68e $41859 \mathrm{~d} 7 \mathrm{fb} 0001 \mathrm{f} 30 \mathrm{c}$ ff/1567155225790/NL2-14_Kjelen.pdf

Kjelen. H. (2015). Litterær kompetanse. Portrett av tre lesarar. Acta Didactica Norge, 9(1). http://dx.doi. org/10.5617/adno. 1390

Kristeva, J. (1980). Word, Dialogue, and Novel. I Desire in Language. A Semiotic Approach to Literature and Art (s. 64-91). New York: Columbia University Press.

Krogh, E., Penne, S. \& Ulfgard, M. (2012). Oppsummering: Den nordiske skolen - fins den? I N. F. Elf \& P. Kaspersen (Red.), Den nordiske skolen - fins den? Didaktiske diskurser og dilemmaer $i$ skandinaviske morsmålsfag (s. 244-259). Oslo: Novus Forlag.

Langer, J. (1995). Envisioning Literature. Literary Undertanding and Literature Instruction. New York: Teachers College.

Lave, J. \& Wenger, E. (1991). Situated Learning. Legitimate Peripheral Participation. Cambridge: Cambridge University Press.

Mariussen, L. U. (2011). Finne deg der inne og hente deg ut. Dikt. Oslo: Oktober.

Nordberg, O. (2017). Avkoppling och analys. Empiriska perspektiv på läsarattityder och litterär kompetens hos svenska 18-åringar (Doktoravhandling, Uppsala universitet). Hentet fra https://uu.diva-portal.org/smash/ get/diva2:1088231/FULLTEXT01.pdf

Notaker, H. (2015). Terrorangrepet 11. september 2001. https://snl.no/Terrorangrepet_11._september_2001

Nussbaum, M. C. (1995). Poetic Fustice. The Literary Imagination and Public Life. Boston: Beacon Press.

Olin-Scheller, C. (2006). Mellan Dante och "Big Brother»: En studie om gymnasieelevers textvärldar. (Doktoravhandling, Karlstad Universitet). Hentet fra http://www.diva-portal.org/smash/get/diva2:6137/ fulltext01.pdfkarlstad

Pandora og Prometevs. (2009). I P. A. Michelsen, J. Krogh, J. K. Hognestad, K.E. Kristoffersen \& B. K. Jansson (Red.), Tema vg1. Norsk språk og litteratur (s. 406-409). Oslo: Det Norske Samlaget.

Penne, S. (2010). Litteratur og film i klasserommet. Didaktikk for ungdomstrinnet og videregående skole. Oslo: Universitetsforlaget.

Penne, S. (2012). Når delen erstatter helheten: litterære utdrag og norskfagets lærebøker. I S. Matre, D. K. Sjøhelle \& R. Solheim (Red.), Teorier om tekst $i$ møte med skolens lese- og skrivepraksiser (s. 163-174). Oslo: Universitetsforlaget.

Penne, S. (2013). Skjønnlitteratur i skolen i et literacy-perspektiv. I D. Skjelbred \& A. Veum (Red.), Literacy $i$ leringskontekster (s. 43-54). Oslo: Cappelen Damm Akademisk.

Schüllerquist, I. M. (2008). Läsa texten eller «verkligheten». Tolkningsgemenskaper på en litteraturdidaktisk bro (Doktoravhandling, Universitetet i Stockholm). Hentet fra http://su.diva-portal.org/smash/get/diva2: 198476/FULLTEXT01.pdf

Rosenblatt, L. (2005). The Transactional Theory of Reading and Writing. I Making Meaning With Texts. Selected Essays (s. 1-37). Portsmouth, NH: Heinemann.

Scholes, R. (1998). The Rise and Fall of English. Reconstructing English as a Discipline. New Haven \& London: Yale University Press.

Skaftun, A. (2009). Litteraturens nytteverdi. Bergen: Fagbokforlaget

Skaftun, A., Aasen, A. J. \& Wagner, Å. K. H. (2015). Fagovergripende og fagspesifikke kompetanser i fremtidens skole - en besøkelsestid for norskfaget? Norsklcereren, 2(15), 50-60. Hentet fra https://static1.squarespace. com/static/5d00b418d9cad80001fc3882/t/5d68e27159d7fb0001f2f709/1567154802598/NL2-15_ Skaftun_Wagner_Aasen.pdf

Skarstein, D. (2013). Meningsdannelse og diversitet. En didaktisk undersøkelse av elevers lesninger av norskfagets littercere tekster (Doktorgradsavhandling, Universitetet i Bergen). Hentet fra http://bora.uib.no/bitstream/ handle/1956/7694/dr-thesis-2013-Dag-Skarstein.pdf?sequence=1\&isAllowed=y

Solbu, K. R. \& Hove, J. O. (2017). Samtidslyrikk i klasserommet. Bergen: LNU/Fagbokforlaget.

Steffensen, B. (2005). Når børn leeser fiktion. Grundlaget for den nye litteraturpadagogik. København: Akademisk Forlag. 
Sønneland, M. (2019). Teksten som problem. En studie av littercere samtaler $i$ ungdomsskolen (Doktoravhandling, Universitetet i Stavanger). Hentet fra http://hdl.handle.net/11250/2630411

Tjora, A. (2013). Kvalitative forskningsmetoder i praksis (2. utg.). Oslo: Gyldendal Akademisk.

Thomassen, M. M. (2016). Litteraturlaboratoriet i praksis. En undersøkelse av hvordan man kan legge til rette for en litteraturdidaktisk praksis $i$ norskfaget som fremmer skjønnlittercer kompetanse (Masteravhandling, Norges teknisk-naturvitenskapelige universitet). Hentet fra http://hdl.handle.net/11250/2403386

Torell, Ö. (2001). Literary Competence Beyond Conventions. Scandinavian fournal of Educational Research, 45(4), 369-379. https://doi.org/10.1080/00313830120096770

Torell, Ö. (Red.), von Bonsdorff, M., Bäckmann, S. \& Gontjarova, O. (2002). Hur gör man en litteraturläsare. Om skolans litteraturundervisning $i$ Sverige, Ryssland och Finland. Härnösand: Mitthögskolan.

Vygotskij, L. (2001). Tenkning og tale. Oslo: Gyldendal. 